\title{
Pengaruh Kompetensi, Integritas, dan Pengembangan Karir Terhadap Kinerja Karyawan Departemen Weaving Produksi pada PT XYZ
}

\author{
${ }^{1}$ Rina Setiastuti, ${ }^{2}$ Juju Zuhriatusobah, ${ }^{3}$ Yulianita Rahayu \\ Universitas Islam Nusantara, Bandung, Jawa Barat, Indonesia \\ Email : ${ }^{1}$ rinasetiastuti7@gmail.com
}

(Diterima: Oktober 2021; Direvisi: Oktober 2021; Dipublikasikan: Januari 2022)

\begin{abstract}
ABSTRAK
Penelitian ini dilakukan pda PT. XYZ, penelitian ini bertujuan untuk menganalisis pengaruh kompetensi, integritas, dan pengembangan karir terhadap kinerja karyawan. Penelitian ini merupakan jenis penelitian kuantitatif, teknik pengumpulan data yang digunakan adalah dengan menyebarkan kuesioner kepada karyawan, menggunakan teknik sampling jenuh dengan tidak merubah populasi. Jumlah populasi yang ada pada Departemen Weaving Produksi PT.XYZ yaitu sebanyak 90 orang. Berdasarkan hasil penelitian ini, disimpulkan bahwa kompetensi dan integritas secara parsial berpengaruh signifikan terhadap kinerja karyawan, sedangkan pengembangan karir tidak berpengaruh signifikan terhadap kinerja keryawan pada Departemen Weaving Produksi PT.XYZ. Hasil uji koefisien determinasi (r-square) kinerja karyawan sebesar 0,380. Kompetensi, integritas, dan pengembangan karir secara simultan mempengaruhi kinerja karyawan sebesar 38\% dan sisanya sebesar $62 \%$ dipengaruhi oleh variabel lain diluar penelitian.
\end{abstract}

\section{Kata Kunci: Kompetensi, Integritas, Pengembangan Karir, Kinerja}




\section{PENDAHULUAN}

Perkembangan bisnis di era globalisasi saat ini semakin pesat, perusahaan ditandai dengan tingkat persaingan yang semakin ketat. Persaingan tidak hanya terjadi pada skala baik nasional maupun internasional, bahkan secara lokal pun persaingan semakin ketat. Hal ini dikarenakan perubahan teknologi yang berinovasi dan dituntut mampu melakukan dinamika perubahan dalam berbagai aspek yang lebih baik.

Sumber daya manusia untuk bisa menjalankan kehidupan dalam sebuah organisasi memiliki peran dan dampak yang sangat penting, hingga saat ini sumber daya manusia masih menjadi faktor penting dalam menentukan keberhasilan organisasi.

Jika organisasi yang dimiliki sumber daya manusia yang berkualitas kurang baik maka akan berpengaruh terhadap organisasi. Jika sumber daya manusia yang berkualitas baik maka akan menghasilkan kinerja yang baik sehingga tercapainya tujuan perusahaan.

Berdasarkan pemerolehan data kinerja Karyawan Departemen Weaving Produksi PT. XYZ dapat dilihat dari hasil pencapaian produksi periode 2019 sebagai berikut:

Tabel 1. Data Target dan Pencapaian Produksi Departemen Weaving Produksi PT. XYZ 2019

\begin{tabular}{|c|c|c|}
\hline Bulan & Target Efisiensi & Pencapaian \\
\hline Januari & $81 \%$ & $81 \%$ \\
\hline Februari & $81 \%$ & $80 \%$ \\
\hline Maret & $81 \%$ & $78 \%$ \\
\hline April & $81 \%$ & $84 \%$ \\
\hline Mei & $81 \%$ & $80 \%$ \\
\hline Juni & $81 \%$ & $80 \%$ \\
\hline Juli & $81 \%$ & $84 \%$ \\
\hline Agustus & $81 \%$ & $79 \%$ \\
\hline September & $81 \%$ & $80 \%$ \\
\hline
\end{tabular}

\begin{tabular}{|c|c|c|}
\hline Oktober & $81 \%$ & $83 \%$ \\
\hline November & $81 \%$ & $81 \%$ \\
\hline Desember & $81 \%$ & $79 \%$ \\
\hline
\end{tabular}

Sumber: Sub. Bagian Produksi Berdasarkan Tabel 1 dapat dilihat bahwa mengenai target dan pencapaian produksi tahun 2019 menunjukkan adanya hasil produksi yang berfluktiasi. Hal ini ditandai dengan adanya hasil produksi yang kurang mencapai target, kekurangan target produksi berdasarkan keterangan dari pihak perusahaan disebabkan oleh adanya kendala pada sistem teknis yaitu mesin produksi. Pencapaian target hasil produksi untuk lima tahun terakhir (20142018) juga mengalami hasil yang berfluktuasi,

Dalam organisasi atau perusahaan untuk menghasilkan kinerja yang baik kompetensi merupakan salah satu faktor penting suatu kinerja. Kompetensi menujukkan keterampilan atau pengetahuan yang dicirikan oleh profesionalisme dalam suatu bidang tertentu.

Departemen Weaving Produksi PT. XYZ pada setiap tahunnya melakukan penilaian kompetensi, penilaian tersebut berdasarkan pengetahuan, keterampilan (skill) dan perilaku. Berikut hasil penilaian pencapaian kompetensi periode 20162020

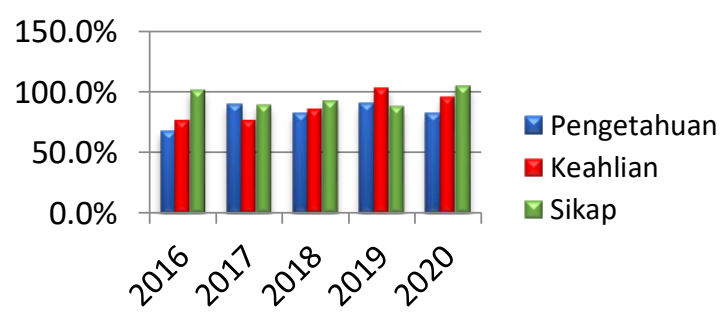

Sumber: HR PT. XYZ 2021 (Diolah Peneliti) Gambar 1. Hasil Penilaian Pencapaian

Kompetensi Karyawan Departemen Weaving Produksi PT. XYZ 2016-2020 
Pada Gambar 1 dapat dilihat bahwa secara keseluruhan data kompetensi karyawan pada periode tahun 2016-2020 menunjukkan adanya penilaian yang berfluktuasi. Dari hasil pengamatan data penilaian yang diperoleh, untuk nilai pengetahuan pada tahun 2018 dan 2020 mengalami penurunan dibandingkan dengan tahun sebelumnya (2019), hal ini disebabkan karena adanya karyawan yang masih kurang memahami flow proses produksi dan standar setting mesin produksi. Untuk nilai keahlian mengalami penurunan pada tahun 2017 dan 2020, disebabkan oleh kurangnya kemampuan karyawan dalam mengendalikan dan menangani gangguan proses produksi. Dan sedangkan untuk nilai sikap mengalami penurunan pada tahun 2017 dan 2019, disebabkan karena masih kurangnya keinisiatifan karyawan dalam melakukan pekerjaan.

Dengan demikian dapat disimpulkan bahwa kompetensi yang dimiliki karyawan kurang optimum, dan mampu berdampak pada pencapaian target kerja perusahaan.

Adapun faktor lainnya yang mempengaruhi kinerja yaitu integritas, integritas mewajibkan individu agar taat terhadap standar teknis dan etika yang dimiliki organisasi atau perusahaan.

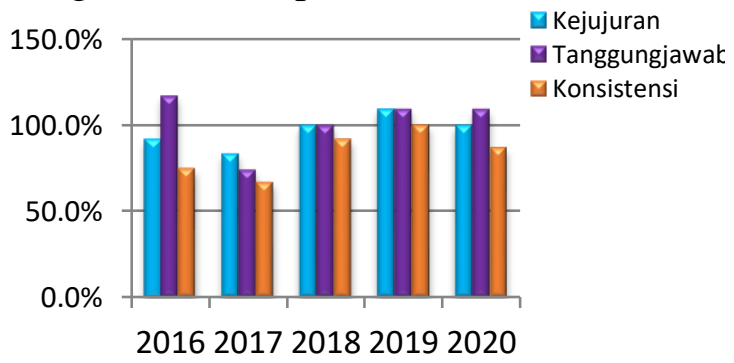

Gambar 2. Hasil Penilaian Pencapaian
Kompetensi Karyawan Departemen Weaving Produksi PT. XYZ 2016-2020 Sumber: HR PT. XYZ 2021 (Diolah Peneliti)

Berdasarkan Gambar 2 dapat dilihat bahwa hasil penilaian integritas pada periode 2016-2020 secara keseluruhan menunjukkan adanya penilaian yang berfluktuasi. Dari hasil wawancara dan pengamatan data, untuk nilai kejujuran mengalami penurunan pada tahun 2017 dan 2020 dibandingkan dengan tahun sebelumnya (2019), hal ini disebabkan karena masih adanya karyawan yang kurang jujur dalam menjalankan tugas pekerjaan. Misalnya pekerjaan yang belum terselesaikan dengan cepat namun ketika saat ditanya oleh atasan karyawan menjawab bahwa tugas telah selesai.

Untuk nilai tanggungjawab mengalami penurunan pada tahun 2017, hal ini disebabkan karena adanya karyawan yang masih kurang bertanggung jawab dalam melakukan tugas pekerjaan. Misalnya pimpinan memerintahkan karyawan untuk bersikap proaktif dalam bekerja, seperti mengingatkan kepada karyawan setelah selesai bekerja menggunakan mesin produksi harus menghentikan atau mematikan mesin terlebih dahulu, namun mesin produksi tersebut tidak dimatikan.

Sedangkan nilai konsistensi pada tahun 2017 dan 2020 mengalami penurunan dibandingkan dengan tahun sebelumnya (2018-2019), hal ini menunjukkan masih rendahnya konsistensi karyawan ketika melakukan pekerjaan. Seperti karyawan kurang berantusias dalam bekerja untuk berteguh pada pendiriannya agar selalu mencapai target sesuai dengan tujuan 
perusahaan. Dengan demikian integritas yang masih rendah akan berdampak pada pencapaian target kerja perusahaan.

Selain adanya faktor kompetensi dan integritas yang mempengaruhi kinerja karyawan, maka adapun faktor lainnya yaitu pengembangan karir yang merupakan usaha dilakukan oleh karyawan untuk meningkatkan kinerja. PT. XYZ dalam pengembangan karir salah satunya yaitu dengan mengadakan promosi jabatan. Pengembangan karir dilakukan perusahaan dengan tahap penyeleksian yang bersifat administratif, seperti berdasarkan hasil penilaian kompetensi, pengalaman masa kerja, tingkat pendidikan karyawan dan memiliki kemampuan berkomunikasi. Untuk seleksi yang dilihat dari masa kerja karyawan, syaratnya adalah minimal karyawan yang sudah bekerja selama 5 tahun, untuk seleksi tingkat pendidikan syaratnya adalah karyawan dengan lulusan minimal D3, namun lulusan SMK/SMA juga bisa saja mendapatkan kenaikan jabatan dengan syarat nilai kompetensi memasuki kriteria perusahaan, dan karyawan harus memiliki kemampuan komunikasi baik secara lisan mau pun tertulis, seperti halnya menyampaikan pendapat atau saran kepada pimpinan dan rekan-rekan kerja dengan baik, sehingga penyampaian dapat diterima.

Dalam hal ini apabila karyawan hanya memiliki kompetensi dan pengalaman masa kerja, namun karyawan tidak mampu berkomunikasi dengan baik, maka akan menjadi penghambat karyawan memperoleh jabatan yang diinginkan.
Berdasarkan latar belakang penelitian di atas, tujuan dari penelitian ini adalah untuk mengetahui kondisi Kompetensi, Integritas, Pengembangan Karir dan Kinerja Karyawan Departemen Weaving Produksi PT. XYZ, serta untuk mengetahui pengaruh Kompetensi, Integritas, dan Pengembangan Karir Terhadap Kinerja Karyawan Departemen Weaving Produksi PT. XYZ secara parsial dan simultan.

\section{TINJAUAN PUSTAKA}

\section{Kompetensi}

$\begin{array}{lr}\text { Menurut } & \text { Wibowo } \\ (2016: 271) \text { "Kompetensi adalah } & \text { antuk } \\ \text { suatu kemampuan r untur }\end{array}$ melaksanakan atau melakukan suatu pekerjaan atau tugas yang dilandasi atas keterampilan dan pengetahuan serta didukung oleh sikap kerja yang dituntut oleh pekerjaan tersebut". Kompetensi menujukkan keterampilan atau pengetahuan yang dicirikan oleh profesionalisme dalam suatu bidang tertentu sebagai sesuatu yang terpenting sebagai unggulan bidang tersebut.

Menurut Zwell dalam Wibowo (2016:283) bahwa terdapat beberapa faktor yang dapat mempengaruhi kompetensi seseorang, yaitu sebagai berikut:

1. Keyakinan Dan Nilai-Nilai

2. Keterampilan

3. Pengalaman

4. Karakteristik Kepribadian

5. Motivasi

6. Isu Emosional

7. Kemampuan Intelektual

Sejumlah

faktor

mempengaruhi kemampuan pekerja untuk memperbaiki 
kecakapan kompetensi yang mempengaruhi kinerjanya. Untuk itu hambatan yang dihadapi perlu diatasi. Menurut Wibowo (2016:286) ada faktor-faktor yang dapat digunakan untuk memperbaiki kompetensi, yaitu sebagai berikut:

1. Admitting

(Mengalami

Kompetensi)

2. Raising (Meningkatkan Harapan)

3. Indentifying (Mengidentifikasi Hambatan)

4. Including Support Mechanism (Memasukkan Mekanisme Dukungan)

Menurut Edison (2017:143) menjelaskan bahwa terdapat dimesi dan indikator untuk memenuhi unsur kompetensi karyawan atau pegawai yaitu sebagai berikut:

1. Pengetahuan (Knowledge)

Memiliki pengetahuan yang didapatkan dari belajar secara formal dan atau dari palatihanpelatihan atau kursus-kursus yang terkait dengan bidang pekerjaan yang ditanganinya.

2. Keahlian (Skill)

Memiliki keahlian terhadap bidang pekerjaan yang ditanganinya dan mampu menanganinya secara detail.

3. Sikap (Attitude)

Menjunjung tinggi etika organisasi dan memiliki sikap positif (ramah dan sopan) dalam bertindak.

\section{Integritas}

Menurut Mohamad Zainuri dan Mahfayeri (2017:4) mengartikan "Integritas adalah sebagai kejujuran dan kebenaran dari tindakkan seseorang dalam kehidupan sehari-hari”.

Adapun menurut Atosokhi dalam Salwa, Away, dan Tabrani (2018:61) bahwa "kata integritas berasal dari akar kata Integreted, yang berarti berbagai bagian dari karakter dan keterampilan berperan akif dalam diri kita yang tampak dari keputusan dan tindakan-tindakan kita”. Menurut Hendarjatno dan Budi Rahardja (2011:118) faktor integritas yang menyatakan hal-hal berhubungan dengan sikap yang menjadi elemen integritas menurut pandangan umum, meliputi:

1. Harus memegang teguh pada prinsip

2. Berperilaku terhormat, yaitu dengan menghindari diri dari segala kecurangan dan praktekpraktek yang melanggar peraturan dan kode etik yang berlaku

3. Jujur

4. Memiliki keberanian untuk melakukan pengungkapan dan menggambil tindakkan yang diperlukan

5. Melakukan tindakkan berdasarkan pada keyakinan akan keilmuan yang tidak ceroboh

6. Tidak bertindak dengan menuruti hawa nafsunya atau membenarkan filosofi tanpa memperhatikan prinsip dan peraturan yang berlaku

Tujuan integritas menurut Henry Cloud (2011) yaitu:

1. Integritas merupakan salah satu kunci untuk meraih keberhasilan atau kesuksesan dalam karir 
2. Integritas mampu membuat manusia untuk memimpin dan dipimpin

3. Integritas melahirkan kepercayaan

4. Integritas dapat melahirkan prestasi kerja

Adapun menurut Henry Cloud (2011) manfaat integritas meliputi:

1. Fisik, Diri merasa fit, sehat, dan bugar merasa siap melaksanakan kegiatan atau pekerjaan sehari-hari.

2. Intelektual, Mental dan pengetahuan

bisamemaksimalkan

pengetahuan dan kemampuan otak.

3. Emosional, Diri menjadi lebih penuh motivasi, sadar diri, empati, simpati, solidaritas tinggi, dan penuh kehangatan emosional dalam interaksi kerja.

4. Spiritual, Membuat diri menjadi bijaksana dalam menilai segala sesuatu termasuk pengalaman hidup, baik yang menyenangkan atau yang tidak membuat senang seperti keberhasilan, kegagalan, dan penderitaan.

5. Sosial, Mampu membuat berkembang suatu hubungan baik satu sama lain dalam lingkungan masyarakat, bisa bekerjasama untuk menyelesaikan tugas atau kegiatan yang menuntut kekompakan dan kerjasama yang baik.

Menurut Abdullah (2019)

bahwa indikator integritas yaitu:

1. Perilaku jujur

2. Sikap konsisten
3. Komitmen terhadap visi dan misi organisasi

4. Objektif terhadap permasalahan

5. Berani mengambil keputusan dan siap menerima resiko

6. Disiplin dan bertanggungjawab

7. Rekam jejak

8. Kinerja

\section{Pengembangan Karir}

Menurut Mangkunegara (2018:77) "Pengembangan karir adalah usaha seseorang dalam upaya perbaikan pribadi untuk mencapai rencana karirnya". Pengembangan karir dapat berhubungan dengan peningkatan kemampuan secara intelektual atau emosional untuk menghasilkan pekerjaan yang lebih baik. Menurut Bianca (2016:173) "pengembangan karir meliputi aktivitas-aktivitas untuk mempersiapkan seorang individu pada kemajuan jalur karir yang direncanakan". Ada beberapa prinsip pengembangan karir yang dapat dijelaskan sebagai berikut:

1. Pekerjaan itu sendiri mempunyai pengaruh yang sangat besar terhadap pengembangan karir.

2. Bentuk pengembangan skill yang dibutuhkan ditentukan oleh permintaan pekerjaan yang spesifik.

3. Pengembangan akan terjadi hanya jika seorang individu belum memperoleh skill yang sesuai dengan tuntutan pekerjaan.

4. Waktu yang digunakan untuk pengembangan dapat direduksi atau dikurangi dengan mengidentifikasi rangkaian penempatan pekerjaan individu yang rasional. 
Menurut Mangkunegara

(2018:77-78) tujuan

pengembangan karir adalah:

1. Membantu dalam pencapaian tujuan individu dan perusahaan

2. Menunjukkan hubungan kesejahteraan karyawan

3. Membantu karyawan menyadari kemampuan potensi mereka

4. Memperkuat hubungan antara karyawan dan perusahaan

5. Membuktikan tanggung jawab sosial

6. Membantu memperkuat pelaksanaan program perusahaan

7. Mengurangi turn over dan biaya kekaryawanan

8. Mengurangi keusangan profesi dan manajerial

9. Menggiatkan analisis dari keseluruhan karyawan

10. Menggiatkan suhu pemikiran jarak waktu yang panjang

Elbadiansyah (2019: 132) menyatakan bahwa manfaat pengembangan karir memberikan dampak positif bagi organisasi maupun karyawan, diantaranya:

1. Menjamin ketersediaan bakat yang diperlukan.

2. Meningkatkan kemampuan organisasi untuk mendapatkan dan mempertahankan karyawan-karyawan yang berkualitas.

3. Menjamin agar kelompokkelompok minoritas dan wanita mempunyai kesempatan yang sama untuk meningkatkan karir.

4. Mengurangi frustasi karyawan.

5. Mendorong adanya keanekaragaman budaya dalam sebuah organisasi.
6. Meningkatkan nama baik organisasi.

Bentuk pengembangan karir yang dapat dilaksanakan menurut Rivai (2016:8) yaitu:

1. Pembinaan dari pimpinan

2. Pendidikan dan pelatihan

3. Promosi dalam manajemen sumber daya manusia

4. Mutasi dan pemindahan

Menurut Busro (2018:278)

Keberhasilan karir seseorang dipengaruhi oleh:

1. Pendidikan formal

2. Pendidikan nonformal yang sesuai dengan bidang kerja yang digeluti

3. Pengalaman kerja

4. Sikap atasan

5. Prestasi kerja yang dicapai selama ini

6. Bobot pekerjaan dalam mendukung pencapaian visi dan misi organisasi

7. Lowongan jabatan

8. Kemampuan manajerial

9. Integritas yang dimiliki

10. Kemampuan komunikasi lisan dan tulis

11. Produktivitas kerja

Menurut Hamriani

(2014:133) indikator variabel pengembangan karir yaitu:

1. Prestasi Kerja

2. Kesempatan

Untuk Berkembang

3. Ekposur

4. Kesetiaan Organisasional

5. Mentor Dan Sponsor

6. Latar Belakang Pendidikan

7. Pengalaman Kerja.

Adapun menurut Sri Rahayu

dan Silvia Anggraini (2019) indikator-indikator dari variabel pengembangan karir, yaitu:

1. Sikap kerja atas rekan kerja 
2. Pengalaman

3. Pendidikan

4. Prestasi

5. Faktor nasib

\section{Kinerja Karyawan}

Menurut Mangkunegara (2018:67) "Kinerja karyawan adalah hasil kerja secara kualitas dan kuantitas yang dicapai oleh seseorang karyawan dalam melaksanakan tugasnya sesuai dengan tanggungjawab yang diberikan kepadanya".

Menurut Mangkunegara (2018:67) faktor-faktor yang mempengaruhi kinerja karyawan yaitu:

1. Faktor kemampuan Secara psikologis, kemampuan (ability) pegawai terdiri dari kemampuan potensi (IQ) dan kemampuan reality (knowledge skill).

2. Faktor motivasi terbentuk dari sikap (attitude) seorang pegawai dalam menghadapi situasi kerja.

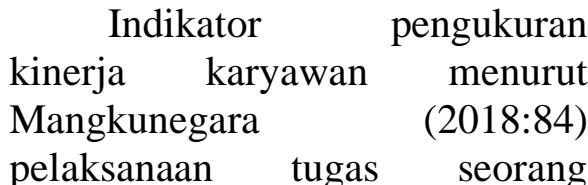
karyawan dalam mencapai hasil kerja baik secara kuantitas maupun kualitas atas dasar tanggungjawab yang diberikan kepadanya. yaitu:

1. Kuantitas merupakan jumlah pekerjaan karyawan yang dihasilkan berdasarkan standar target kerja yang ditetapkan dalam kurun waktu tertentu

2. Kualitas merupakan ketelitian, keterampilan, dan kesesuaian atas hasil pekerjaan seseorang berdasarkan standar kerja yang ditetapkan dalam kurun waktu tertentu
3. Ketepatan waktu merupakan kemampuan seorang karyawan dalam menyelesaikan pelaksanaan tugas yang menjadi tanggungjawabnya sesuai dengan jangka waktu yang tertentu

\section{Kerangka Pemikiran}

Menurut Sugiyono (2019)

Kerangka pemikiran merupakan penjelasan sementara terhadap gejala-gejala yang menjadi obyek penelitian. Dalam kerangka penelitian ini menunjukkan pengaruh Kompetensi, Integritas Dan Pengembangan Karir Terhadap Kinerja Karyawan.

Kompetensi karyawan yang baik sangat penting untuk kelangsungan sebuah perusahaan, semakin tinggi tingkat kompetensi karyawan maka kemampuan dalam penyelesain tugas pekerjaan akan semakin baik. Menurut Ansori dan Ali (2017) kompetensi mempengaruhi kinerja karyawan, menjelaskan jika suatu perusahaan atau organisasi dapat menugaskan karyawan sesuai dengan kompetensinya, baik kompetensi teknis maupun non teknis. Berdasarkan hasil penelitian Annisa Puteri dan Alini Gilang (2018) hasil analisis menunjukkan kompetensi berpengaruh positif dan signifikan terhadap kinerja karyawan.

Integritas berkaitan dengan kinerja, suatu pencapaian hasil yang dicapai dengan selalu menunjang tinggi kejujuran nilainilai moral lainnya, sehingga integritas muncul dalam bentuk kinerja atau hasil kerja yang baik. Berdasarkan hasil penelitian Sujiyanto (2017) menyatakan 
bahwa integritas berpengaruh positif dan signifikan terhadap kinerja karyawan. Hal ini menunjukkan bahwa jika integritas yang dimiliki semakin tinggi maka kinerja karyawan juga akan semakin tinggi.

Pengembangan karir usaha yang dilakukan oleh karyawan bertujuan untuk meningkatkan kinerja dalam meraih keberhasilan, dan kesuksesan organisasi atau perusahaan. Menurut Siagian (2016) "pengembangan karir merupakan setiap karyawan harus mempunyai gambaran yang jelas mengenai anak tangga tertinggi apa yang bisa dicapai selama menampilkan kinerja yang memuaskan".

Berdasarkan hasil penelitian oleh Hadi Arifin, Hendra Reza, dkk (2020) hasil analisis menunjukan bahwa pengembangan karir berpengaruh signifikan dan positif terhadap kinerja karyawan secara parsial.

Berdasarkan pemikiran di atas maka dapat dilihat gambar bagan penelitian sebagai berikut:

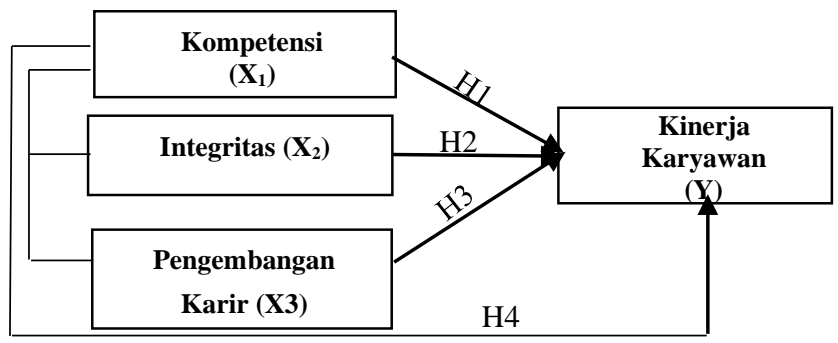

Sumber: Diolah peneliti 2021

Gambar: 3

Kerangka Penelitian

Berdasarkan

kerangka pemikiran, maka merumuskan hipotesis dalam penelitian ini sebagai berikut:

H1: Diduga kompetensi berpengaruh signifikan terhadap kinerja karyawan Departemen Weaving Produksi PT. XYZ secara parsial. $\mathrm{H} 2$ : Diduga integritas berpengaruh signifikan terhadap kinerja karyawan Departemen Weaving Produksi PT. XYZ secara parsial.

H3: Diduga pengembangan karir berpengaruh signifikan terhadap kinerja karyawan Departemen Weaving Produksi PT. XYZ secara parsial.

H4: Diduga kompetensi, integritas, dan pengembangan karir berpengaruh signifikan terhadap kinerja karyawan Departemen Weaving Produksi Pada PT. XYZ secara simultan.

\section{METODE PENELITIAN}

Yang digunakan dalam penelitian ini yaitu data kuantitatif berasal dari wawancara dan kuesioner yang diberikan kepada karyawan Departemen Weaving Produksi PT. XYZ. Populasi dalam penelitian ini yaitu 90 orang karyawan bagian operasional pada Departemen Weaving Produksi PT. XYZ.

Dalam penelitian ini pengambilan sampel diambil dalam teknik sampling jenuh. Menurut Sugiyono (2019:127) "Sampling jenuh adalah sampling yang sudah maksimum, karena ditambah berapapun jumlahnya tidak akan merubah keterwakilan populasi, yang merupakan teknik penentukan sampel bila semua anggota populasi digunakan sebagai sampel". Jumlah populasi yang ada pada Departemen Weaving Produksi PT. XYZ yaitu sebanyak 90 orang responden, keseluruhan populasi tersebut dijadikan sampel dalam penelitian ini. 
Teknik Pengumpulan Data

Data yang dibutuhkan dalam penelitian ini dikelompokan menjadi dua jenis, yaitu:

1. Data Primer

Menurut Sugiyono (2019:296) mendefinisikan bahwa "Data primer adalah sumber data yang langsung memberikan data kepada pengumpul data" diperoleh melalui kuesioner dan wawancara terstruktur berupa identitas responden, yang berupa:

a. Observasi

Teknik pengamatan atau observasi merupakan kegiatan pemuatan penelitian terhadap suatu objek.

b. Wawancara

Teknik wawancara merupakan pertemuan dua orang untuk bertukar informasi dan ide melalui tanya jawab. Dalam penelitian ini wawancara dilakukan kepada karyawan sekaligus pihak personalia PT. XYZ.

c. Kuesioner

Teknik kuesioner adalah suatu teknik pengumpulan informasi yang memungkinkan analisis mempelajari sikapsikap, keyakinan, perilaku, dan karakteristik beberapa orang utama di dalam organisasi yang bisa terpengaruh oleh sistem yang diajukan atau oleh sistem yang sudah ada. Dalam penelitian ini kuesioner disebarkan kepada karyawan Departemen Weaving Produksi PT. XYZ untuk mengetahui tanggapan responden tentang kompetensi, integritas, pengembangan karir dan kinerja karyawan. Bentuk kuesioner bersifat tertutup yaitu setiap karyawan diberi alternatif pilihan jawaban pada setiap pertanyaan. Seluruh veriabel akan diukur menggunakan Skala Likert. Jawaban setiap item instrumen yang menggunakan Skala Likert mempunyai gradasi dari sangat positif sampai negatif yang dapat berupa kata-kata antara lain:

a. Sangat Setuju (SS): Skor 5

b. Setuju (S): Skor 4

c. Ragu-Ragu (R) Skor 3

d. Tidak Setuju (TS): Skor 2

e. Sangat Tidak setuju (STS): Skor 1

2. Data Sekunder Menurut

Sugiyono (2019:137) "Data sekunder merupakan sumber yang tidak langsung memberikan data kepada pengumpul data, misalnya lewat orang lain atau lewat dokumen". Data sekunder dalam penelitian ini diperoleh dengan cara membaca dokumen yang ada hubungannya dengan masalah yang akan diteliti dalam penyusunan skripsi.

\section{Variabel Penelitian dan}

\section{Operasionalisasi Variabel}

1. Variabel Penelitian Variabel Independen

Menurut Sugiyono (2019) "variabel bebas (independent variable) adalah variabel yang mempengaruhi atau yang menjadi sebab perubahannya atau timbulnya variable dependent (terikat)". Variabel bebas yang digunakan dalam penelitian ini adalah Kompetensi ( $\left.\mathbf{X}_{\mathbf{1}}\right)$, Integritas 
$\left(\mathbf{X}_{2}\right)$, dan Pengembangan Karir $\left(\mathbf{X}_{3}\right)$.

$$
\text { Sedangkan }
$$

Dependen menurut

Variabel (2019) "variabel terikat (dependent variable) adalah variabel yang dipengaruhi atau yang menjadi akibat karena adanya variabel bebas (independent variable)". Variabel ini disebut juga variabel output, kriteria, dan konsekuen. Variabel terikat yang digunakan dalam penelitian ini adalah Kinerja Karyawan (Y).

2. Operasionalisasi Variabel

Operasionalisasi variabel dilakukan dengan menjelaskan dimensi dan indikator dari setiap variabel, masing-masing indikator dijadikan sebagai dasar penyusunan butir-butir pertanyaan kuesioner.

Berikut operasionalisasi variabel yang telah peneliti ambil:

Tabel 2

Operasional Variabel

\begin{tabular}{|c|c|c|c|c|}
\hline Variabel & Konsep Variabel & Dimensi & Indikator & Skala \\
\hline \multirow[t]{5}{*}{$\begin{array}{c}\text { Kompetensi } \\
\left(\mathbf{X}_{1}\right)\end{array}$} & \multirow{5}{*}{$\begin{array}{l}\text { Kompetensi adalah perpaduan } \\
\text { pengetahuan, keterampilan, sikap, } \\
\text { dan karakteristik pribadi lainnya } \\
\text { yang diperlukan untuk mencapai } \\
\text { keberhasilan dalam sebuah } \\
\text { pekerjaan yang bias diukur dengan } \\
\text { menggunakan standar yang telah } \\
\text { disepakati, dan yang dapat } \\
\text { ditingkatkan melalui pelatihan dan } \\
\text { pengembangan. } \\
\text { (Marwansyah, 2016:36) }\end{array}$} & Pengetahuan & $\begin{array}{l}\text { Pengetahuan } \\
\text { melaksanakan } \\
\text { tugas pekerjaan } \\
\end{array}$ & \multirow[t]{5}{*}{ Ordinal } \\
\hline & & \multirow[t]{3}{*}{ Keahlian (Skill) } & $\begin{array}{l}\text { Kemampuan } \\
\text { melaksanakan } \\
\text { tugas kerja sesuai } \\
\text { intruksi }\end{array}$ & \\
\hline & & & $\begin{array}{l}\text { Kemampuan } \\
\text { mengoperasikan } \\
\text { tugas kerja }\end{array}$ & \\
\hline & & & $\begin{array}{l}\text { Kemampuan } \\
\text { menyelesaikan } \\
\text { dan memecahkan } \\
\text { masalah }\end{array}$ & \\
\hline & & Sikap Kerja & $\begin{array}{l}\text { Kesopanan, dan } \\
\text { inisiatif dalam } \\
\text { bekerja }\end{array}$ & \\
\hline \multirow[t]{3}{*}{ Integritas $\left(\mathbf{X}_{2}\right)$} & \multirow{3}{*}{$\begin{array}{l}\text { Integritas adalah sebagai kejujuran } \\
\text { dan kebenaran dari tindakkan } \\
\text { seseorang dalam kehidupan sehari- } \\
\text { hari } \\
\text { Mohamad Zainuri dan Mahfayeri } \\
(2017: 4)\end{array}$} & Kejujuran Kerja & $\begin{array}{l}\text { Kejujuran } \\
\text { karyawan } \\
\text { menjalankan } \\
\text { pekerjaan }\end{array}$ & \multirow[t]{3}{*}{ Ordinal } \\
\hline & & Bertanggungjawab & $\begin{array}{l}\text { Tanggungjawab } \\
\text { karyawan dalam } \\
\text { bekerja }\end{array}$ & \\
\hline & & Konsisten kerja & $\begin{array}{l}\text { Konsistensi } \\
\text { karyawan dalam } \\
\text { bekerja. }\end{array}$ & \\
\hline \multirow[t]{4}{*}{$\begin{array}{c}\text { Pengembangan } \\
\operatorname{Karir}\left(\mathbf{X}_{3}\right)\end{array}$} & \multirow{3}{*}{$\begin{array}{l}\text { Pengembangan karir merupakan } \\
\text { proses dimana karyawan } \\
\text { memperoleh keterampilan dan } \\
\text { pengalaman agar berhasil pada } \\
\text { pekerjaan sekarang dan tugas- } \\
\text { tugas dimasa yang akan datang. }\end{array}$} & $\begin{array}{l}\text { Latar belakang } \\
\text { Pendidikan }\end{array}$ & $\begin{array}{l}\text { Pendidikan } \\
\text { karyawan }\end{array}$ & \multirow[t]{4}{*}{ Ordinal } \\
\hline & & Pengalaman kerja & $\begin{array}{l}\text { Pengalaman } \\
\text { kerja karyawan }\end{array}$ & \\
\hline & & Hamriani (2014) & $\begin{array}{l}\text { Kesempatan } \\
\text { karyawan } \\
\text { menduduki } \\
\text { jabatan tertentu }\end{array}$ & \\
\hline & Kaswan (2013:2) & & & \\
\hline Kinerja (Y) & Kinerja merupakan hasil pekerjaan & Kualitas Kerja & $\begin{array}{l}\text { Kerusakan hasil } \\
\text { produksi }\end{array}$ & Ordinal \\
\hline
\end{tabular}




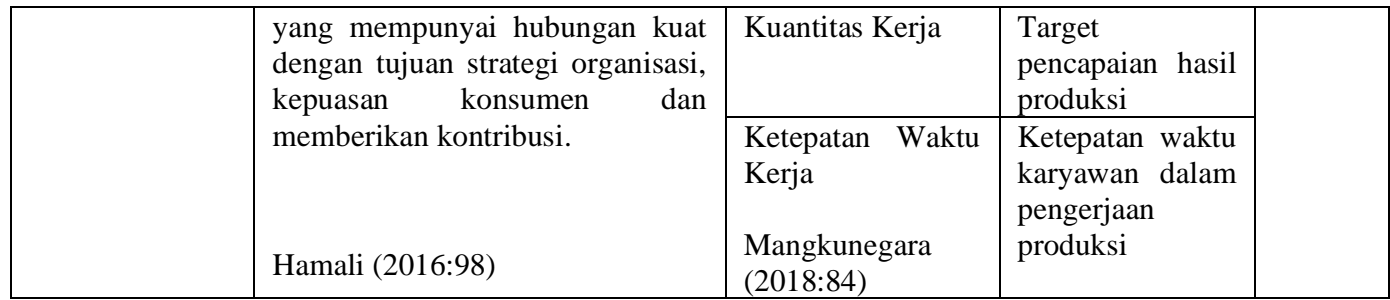

\section{Model Analisis Data}

Dalam penelitian ini metode analisis data yang digunakan adalah structural equation modeling-partial least squares (SEM-PLS) dengan menggunakan software SmartPLS versi 3.0.

\section{Uji Model Pengukuran (Outer Model)}

Menurut Ghozali (2015)

"Model pengukuran (outer model) sering juga disebut outer relation atau measurement mode, mendefinisikan bagaimana setiap blok indikator berhubungan dengan variabel latennya". Kriteria untuk menilai model pengukurannya yaitu:

1. Uji Convergent Validity

Menurut Mahfud dan Ratmono (2013:64) "Validitas Konvergen (Convergent Validity) merupakan bagian dari measurement model (model pengukuran) yang dalam SEMPLS biasanya disebut sebagai outer model sedangkan dalam covariance-based SEM disebut confirmatory factor analysis (CFA)".

2. Uji Validity Discriminant

Menurut Ghozali dan
Hengky (2015) "adalah
membandingkan nilai Square Root Of Average Variance Extracted (AVE) setiap konstruk dengan korelasi antara konstruk lainnya dalam model". Jika nilai akar AVE setiap konstruk lebih besar daripada nilai korelasi antar konstruk dengan konstruk lainnya dalam model, maka dikatakan memiliki nilai discriminant validity yang baik. Direkomendasikan nilai AVE harus lebih besar dari 0,50.

3. Uji Composite Reliability

Composite reliability merupakan blok indikator yang mengukur suatu konstruk dapat dievaluasi. Ghozali dan Hengky (2015) "menyatakan suatu variabel laten memiliki reliabilitas yang tinggi apabila nilai composite reliability di atas 0,60 ".

Uji Model Struktural (Inner Model)

Menurut (Ghozali, 2015)

"Inner Model sering juga disebut dengan inner relation, structural model dan substantive theory, menggambarkan hubungan antar variabel laten berdasarkan pada substantive theory". Kriteria model struktural dijelaskan sebagai berikut:

1. Analisis Jalur (Path Analisys)

Menurut (Ghozali, 2015) "Analisis jalur berfungsi untuk menguji besarnya kontribusi yang ditunjukkan koefisien jalur pada setiap diagram jalur dari hubungan kausal antar konstruk". Path Analysis akan mengungkapkan pengaruh langsung dan pengaruh tidak langsung antar konstruk, didasarkan pada koefisien regresi yang standardized.

2. Uji Nilai Koefisien Determinasi $R$ Square $\left(\mathrm{R}^{2}\right)$ 
Menurut (Ghozali, 2015) "Koefisien determinasi digunakan untuk melihat kemampuan model atau kemampuan variabel independen dalam menjelaskan variansi data pada variabel dependen. Nilai $\mathrm{R}^{2}$ sebesar 0.67 , 0.33 , dan 0.19 mengindikasikan bahwa model baik, moderat, dan lemah".

3. Uji Effect Size $\left(\mathrm{f}^{2}\right)$

Menurut (Ghozali, 2015) "Nilai effect size $\left(f^{2}\right)$ menunjukkan interaksi antara variabel independen dengan variabel moderating dalam mempengaruhi variabel dependen. Untuk membentuk konstruk interaksi dilakukan dengan cara mengalikan indicator X dan Z". Effect size (efek moderasi) digunakan untuk mengukur kontribusi antar masing-masing variabel terhadap bentukan $\mathrm{R}^{2}$ dengan melihat nilai $\mathrm{f}^{2}$ yaitu $0.02,0.15$, dan 0.35 yang menunjukkan bahwa model lemah, moderat dan kuat. Effect size untuk model moderating dapat dihitung dengan menggukan rumus:

$$
f^{2}=\frac{R^{2} \text { Model Moderasi }-R^{2} \text { Model Tanpa Moderasi }}{1-R^{2} \text { Model Moderasi }}
$$

\section{HASIL PENELITIAN}

\section{Uji Validitas Konvergen}

Terdapat dua kriteria untuk menilai apakah outer model (model pengukuran) memenuhi syarat validitas konvergen untuk konstruk reflektif, yaitu:

1. Loading harus di atas 0,7

2. Nilai $p$ signifikan atau nilai batasan Average Variance Extract $(<0,05)$
Uji validitas konvergen disajikan dengan nilai loading faktor untuk setiap indikator.

Hasil uji validitas lodiang faktor sebagai berikut:

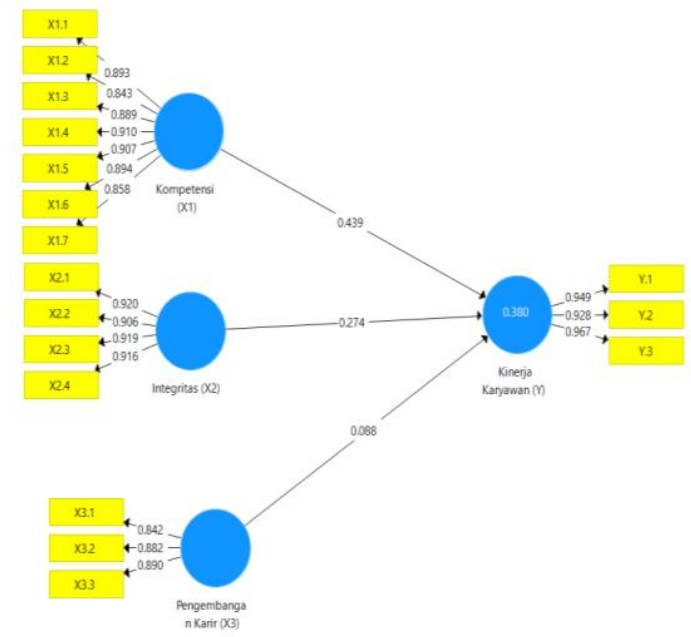

Sumber: Data Primer Yang Diolah (2021)

Gambar 4. Pengujian Validitas berdasarkan Loading Faktor

Berdasarkan pengujian validitas loading faktor pada Gambar 4, seluruh indikator variabel bernilai loading > 0,7 , yang berarti telah memenuhi syarat validitas berdasarkan nilai loading.

\section{Uji validitas Average Variance} Extracted (AVE)

Tabel 3. Pengujian Validitas berdasarkan Average Variance Extracted (AVE)

\begin{tabular}{|l|c|}
\hline & $\begin{array}{c}\text { Average Variance } \\
\text { Extracted (AVE) }\end{array}$ \\
\hline Integritas (X2) & 0.838 \\
\hline Kinerja Karyawan (Y) & 0.899 \\
\hline Kompetensi (X1) & 0.783 \\
\hline $\begin{array}{l}\text { Pengembangan Karir } \\
\text { (X3) }\end{array}$ & 0.760 \\
\hline
\end{tabular}

Sumber : Data Primer Yang Diolah (2021) Berdasarkan table 3 diketahui seluruh nilai AVE > 0,5, yang berarti variabel kompetensi, integritas, pengembangan karir, dan kinerja karyawan telah memenuhi syarat validitas berdasarkan AVE. 
Uji Descriminant Validity (Validitas Diskriminan)

Tabel 4. Pengujian Validitas Diskriminan

\begin{tabular}{lcc}
\hline \multicolumn{1}{c}{ Variabel } & $\begin{array}{c}\text { Nilai akar } \\
\text { AVE }\end{array}$ & Kriteria \\
\hline $\begin{array}{l}\text { Kompetensi } \\
\text { (X1) }\end{array}$ & 0,885 & $>0,50$ \\
\hline Integritas (X2) & 0,915 & $>0,50$ \\
\hline $\begin{array}{l}\text { Pengembangan } \\
\text { Karir (X3) }\end{array}$ & 0,872 & $>0,50$ \\
\hline $\begin{array}{l}\text { Kinerja } \\
\text { Karyawan (Y) }\end{array}$ & 0,948 & $>0,50$ \\
\hline \begin{tabular}{l} 
Sumber : Data Primer Yang Diolah (2021) \\
\multicolumn{2}{c}{ Menurut }
\end{tabular} & \multicolumn{2}{l}{ Ghozali }
\end{tabular}

Hengky (2015) dikatakan memiliki nilai discriminant validity yang baik, maka nilai akar AVE harus lebih besar dari 0,50. Berdasarkan tabel 4 maka dapat disimpulkan bahwa variabel kompetensi, integritas, pengembangan karir, dan kinerja karyawan tersebut menunjukkan hasil nilai akar AVE >0,50 sehingga memenuhi syarat validitas determinan.

\section{Uji Reliability (Reabilitas)}

Menurut Ghozali dan Latan (2015:39) "Evaluasi reliabilitas dinilai berdasarkan alpha cronbach dan composite reliability. Nilai alpha cronbach yang disarankan adalah di atas 0,7. Sementara nilai batasan composite reliability di atas $0,7 . "$

Tabel 5. Pengujian Reliabilitas berdasarkan Composite Reliability (CR)

\begin{tabular}{|l|c|}
\hline & Composite Reliability \\
\hline Integritas (X2) & 0.954 \\
\hline Kinerja Karyawan (Y) & 0.964 \\
\hline Kompetensi (X1) & 0.962 \\
\hline $\begin{array}{l}\text { Pengembangan Karir } \\
\text { (X3) }\end{array}$ & 0.905 \\
\hline
\end{tabular}

Sumber : Data Primer Yang Diolah (2021) Berdasarkan tabel 6 diketahui bahwa seluruh nilai $\mathrm{CR}$ $>0,7$, yang berarti variabel kompetensi, integritas, pengembangan karir, dan kinerja karyawan telah memenuhi syarat reliabilitas berdasarkan Composite Reliability (CR).

Tabel 6. Pengujian Reliabilitas berdasarkan Cronbach's Alpha (CA)

\begin{tabular}{|c|c|}
\hline & Cronbach's Alpha \\
\hline Integritas (X2) & 0.936 \\
\hline Kinerja Karyawan (Y) & 0.943 \\
\hline Kompetensi (X1) & 0.954 \\
\hline $\begin{array}{c}\text { Pengembangan Karir } \\
\text { (X3) }\end{array}$ & 0.842 \\
\hline
\end{tabular}

Sumber : Data Primer Yang Diolah (2021) Berdasarkan tabel 6 diketahui bahwa seluruh nilai CA $>0,7$, yang berarti variabel kompetensi, integritas, pengembangan karir, dan kinerja karyawan telah memenuhi syarat reliabilitas berdasarkan Cronbach's Alpha (CA).

4. Uji Model Struktural (Inner Model)

Inner model dapat dievaluasi dengan melihat $r$-square. Semakin tinggi nilai $r$-square berarti semakin baik model prediksi dari model peneliti yang diajukan.

Tabel 7. Koefisien Determinasi $(R$ -

\begin{tabular}{lll}
\multicolumn{3}{c}{ Square) } \\
\hline & $\begin{array}{l}\mathbf{R} \\
\text { Squa } \\
\text { re }\end{array}$ & $\begin{array}{l}\text { R Square } \\
\text { Adjusted }\end{array}$ \\
\hline $\begin{array}{l}\text { Kinerja } \\
\text { Karyawan (Y) }\end{array}$ & 0,380 & 0,358 \\
\hline
\end{tabular}

Sumber: Data Primer Yang Diolah (2021)

Berdasarkan hasil pada tabel 7 , diketahui nilai koefisien determinasi (r-square) dari kinerja karyawan adalah 0,380. Nilai tersebut dapat diinterpretasi bahwa kompetensi, integritas, dan pengembangan karir secara simultan atau bersama-sama mempengaruhi kinerja karyawan sebesar $38 \%$, dan sisanya sebesar $62 \%$ dipengaruhi oleh variabel lain diluar penelitian. 
5. Pengujian Hipotesis

Tabel 8. Uji Signifikansi Pengaruh

\begin{tabular}{|c|c|c|c|c|c|}
\hline & $\begin{array}{c}\text { Origi } \\
\text { nal } \\
\text { Sam } \\
\text { ple } \\
(0)\end{array}$ & $\begin{array}{c}\text { Sam } \\
\text { ple } \\
\text { Mea } \\
n \\
\text { (M) }\end{array}$ & $\begin{array}{c}\text { Standa } \\
\text { rd } \\
\text { Deviati } \\
\text { on } \\
\text { (STDEV }\end{array}$ & $\begin{array}{c}\text { T } \\
\text { Statist } \\
\text { ics } \\
(\mid \mathrm{O} / \mathrm{ST} \\
\mathrm{DEV} \mid)\end{array}$ & $\begin{array}{c}\text { P } \\
\text { v } \\
\text { al } \\
\text { u } \\
\text { es }\end{array}$ \\
\hline $\begin{array}{l}\begin{array}{l}\text { Kompetensi } \\
(\mathrm{X} 1) \quad> \\
\text { Kinerja } \\
\text { Karyawan }(\mathrm{Y})\end{array} \\
\end{array}$ & 0.439 & $\begin{array}{c}0.42 \\
8\end{array}$ & 0.132 & 3.332 & $\begin{array}{c}0 . \\
00 \\
1\end{array}$ \\
\hline $\begin{array}{l}\text { Integritas } \\
\text { (X) } \\
\text { Kinerja } \\
\text { Karyawan (Y) }\end{array}$ & 0.274 & $\begin{array}{c}0.28 \\
3\end{array}$ & 0.135 & 2.034 & $\begin{array}{c}0 . \\
04 \\
2\end{array}$ \\
\hline $\begin{array}{l}\text { Pengembang } \\
\text { an Karir (X3) - } \\
\text { Kinerja } \\
\text { Karyawan (Y) }\end{array}$ & 0.088 & $\begin{array}{c}0.09 \\
9\end{array}$ & 0.116 & 0.762 & $\begin{array}{c}0 . \\
44 \\
6\end{array}$ \\
\hline umber : D & $T$ & & $\bar{D}$ & ( & \\
\hline
\end{tabular}

diketahui nilai koefisien jalur kompetensi terhadap kinerja karyawan adalah 0,439 (kolom original sample), dengan nilai $\mathrm{P}$ Values $=0,001<0,05$, maka disimpulkan kompetensi Departemen Weaving Produksi PT. XYZ secara parsial berpengaruh signifikan terhadap kinerja karyawan. Dengan demikian hipotesis pertama (H1) diterima. Semakin tinggi tingkat kompetensi karyawan maka kemampuan dalam penyelesain tugas pekerjaan akan semakin baik.

Diketahui nilai koefisien jalur integritas terhadap kinerja karyawan adalah 0,274 (kolom original sample), dengan nilai $\mathrm{P}$ Values $=0,042<0,05$, maka disimpulkan integritas Departemen Weaving Produksi PT. XYZ secara parsial berpengaruh signifikan terhadap kinerja karyawan. Dengan demikian hipotesis kedua $(\mathrm{H} 2)$ diterima.

Diketahui nilai koefisien jalur pengembangan karir terhadap kinerja karyawan adalah 0,088 (kolom original sample), dengan nilai $\mathrm{P}$-Values $=0,446>0,05$, maka disimpulkan pengembangan karir Departemen Weaving Produksi PT. XYZ secara parsial tidak berpengaruh signifikan terhadap kinerja karyawan. Dengan demikian hipotesis ketiga (H3) ditolak.

\section{Pembahasan}

Berdasarkan hasil penelitian hipotesis secara parsial, kompetensi berpengaruh signifikan terhadap kinerja karyawan Departemen Weaving Produksi PT.XYZ. Hasil penelitian ini sejalan dengan penelitian Annisa Putri dan Alini Gilang (2018) hasil analisis menunjukkan kompetensi berpengaruh positif dan signifikan terhadap kinerja karyawan. Ansori dan Ali (2017) memberikan pengertian bahwa kompetensi mempengaruhi kinerja karyawan, menjelaskan jika suatu perusahaan atau organisasi dapat menugaskan karyawan sesuai dengan kompetensinya, baik kompetensi teknis maupun non teknis.

Berdasarkan hasil penelitian hipotesis secara parsial, integritas berpengaruh signifikan terhadap kinerja karyawan Departemen Weaving Produksi PT.XYZ. Hasil penelitian ini sejalan dengan hasil penelitian Sujiyanto (2017) menyatakan bahwa integritas berpengaruh positif dan signifikan terhadap kinerja karyawan. Melasari, Rianti (2017) memberi pengertian bahwa dengan integritas karyawan menciptakan lingkungan kerja yang berharga, sehingga karyawan dapat lebih fokus pada situasi jangka panjang yang lebih baik untuk perusahaan. 
Berdasarkan hasil penelitian hipotesis secara parsial, pengembangan karir tidak berpengaruh signifikan terhadap kinerja karyawan Departemen Weaving Produksi PT. XYZ. Hasil penelitian ini sejalan dengan penelitian Gian, Greis \& Hendra (2017) hasil analisis menunjukkan bahwa secara parsial pengembangan karir tidak berpengaruh signifikan terhadap kinerja karyawan. Begitu juga sejalan dengan penelitian Leti \& Sri (2019) hasil analisis menunjukkan pengembangan karir berpengaruh tidak signifikan terhadap variabel kinerja karyawan. Adapun hasil penelitian Noviyanti \& Sri (2019) menunjukkan bahwa variabel pengembangan karir tidak berpengaruh terhadap kinerja karyawan.

Berdasarkan hasil uji signifikansi, maka berikut bagan alur penelitian pengaruh kompetensi, integritas, dan pengembangan karir terhadap kinerja karyawan dapat dilihat sebagai berikut:

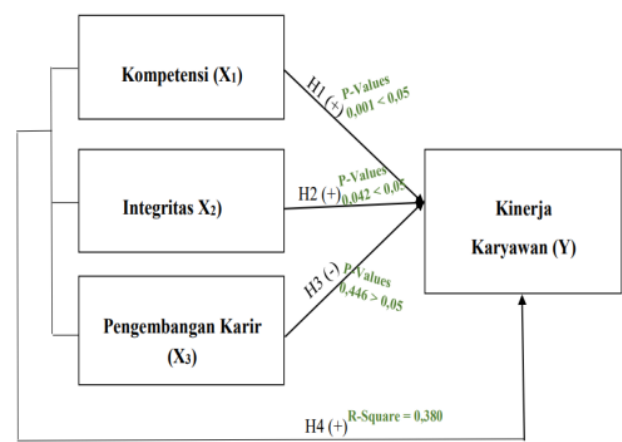

Sumber: Data Primer Yang Diolah (2021) Gambar 5

Bagan Hasil Penelitian

\section{KESIMPULAN}

Kompetensi memiliki rata-rata penilaian responden sebesar 4,24, yang berarti kompetensi pada Departemen Weaving Produksi PT. XYZ berada pada kriteria sangat baik. Integritas memiliki rata-rata sebesar 4,32, yang berarti integritas pada Departemen Weaving Produksi PT. XYZ berada pada kriteria sangat baik. Pengembangan Karir memiliki ratarata sebesar 3,93, yang berarti pengembangan karir pada Departemen Weaving Produksi PT. XYZ berada pada kriteria baik. Dan Kinerja Karyawan memiliki rata-rata sebesar 4,20 yang berarti kinerja karyawan pada Departemen Weaving Produksi PT. XYZ berada pada kriteria baik.

Berdasarkan uji signifikan kompetensi (X1) nilai P-Values = $0,001<0,05$, maka kompetensi memiliki pengaruh signifikan terhadap kinerja karyawan. Integritas (X2) dengan nilai P-Values $=0,042<$ 0,05 , maka integritas memiliki pengaruh signifikan terhadap kinerja karyawan. Dan pengembangan karir (X3) dengan nilai P-Values $=0,446>$ 0,05 , maka pengembangan karir tidak berpengaruh signifikan terhadap kinerja karyawan. Dengan demikian kompetensi dan integritas secara parsial berpengaruh signifikan terhadap kinerja karyawan, sedangkan pengembangan karir tidak berpengaruh signifikan terhadap kinerja keryawan pada Departemen Weaving Produksi PT XYZ.

Berdasarkan hasil uji koefisien determinasi (r-square) dari kinerja karyawan adalah 0,380. Dapat disimpulkan bahwa kompetensi, integritas, dan pengembangan karir Departemen Weaving Produksi PT. 
PT.XYZ secara simultan mempengaruhi kinerja karyawan sebesar $38 \%$ dan sisanya sebesar $62 \%$ dipengaruhi oleh variabel lain diluar penelitian yaitu variabel Karakteristik Individu.

\section{DAFTAR PUSTAKA}

Abdullah. (2019). Integritas Menyemai Kejujuran, Menuai Kesuksesan \& Kebahagiaan. Yogyakarta: The Phinisi Press. Annisa Putri, \& Alini Gilang. (2018). Pengaruh Kompetensi Terhadap Kinerja Karyawan (Studi di PT. Telekomunikasi Indonesia Tbk Witel Bandung). Jurnal Riset Bisnis dan Manajemen, Volume VIII No.1(1), 62-75.

Ansori, \& Ali. (2017). Analisis Pengaruh Kompetensi dan Promosi Terhadap Kinerja Pegawai Negri Sipil Pada Sekretariat Daerah Kabupaten Bungo. Jurnal Ilmiah Universitas Batanghari Jambi.

Bianca, dkk. (2016). Pengaruh Motivasi, Pengembangan Karr, dan Kepuasan Kerja Terhadap Kinerja Karyawan dengan Metode Structural Equation Modelling. Jurnal Teknik Industri, Vol. 1(No. 4), 334340.

Busro. (2018). Teori-Teori Manajemen Sumber Daya Manusia. Jakarta: Prenada Media Grup.

Elbadiansyah. (2019). Manajemen Sumber Daya Manusia. Purwokerto: CV IRDH.

Ghozali, \& Latan H. (2015). Partial Least Square Konsep, Teknok dan Aplikasi Menggunakan Program SmartPLS 3.0 Untuk
Peneliti Empires. Semarang: Badan Penerbit Universitas Diponegoro.

Gian, Greis, \& Hendra N. (2017). Pengaruh Pengembangan Karir, Pengalaman Kerja, Dan Keterlambatan Kerja Terhadap Kinerja Karyawan PT. Bank Rakyat Indonesia (Persero) Tbk Kantor Cabang Manado.

Hadi Arifin, Hendra Reza, Jumadil Saputra, \& Anwar Puteh. (2020). The Influence Of Recruitment And Career Development Towards Employee Performance: A Mediating Role Of Competence. International Research Association For Talent Development and Excellence, Vol 12(No.1), 1040-1055.

Hamriani. (2014). Manajemen Sumber Daya Manusia. Makasar: University Press.

Hendarjatno, \& Budi Rahardja. (2013, Agustus). Persepsi Masyarakat Perbankan di Surabaya Terhadap Integritas, Objektivitas dan Independensi Akuntan Publik. Universitas Airlangga, Vol. XIII (No. 12).

Henry Could. (2011). Integritas keberanian Memenuhi Tuntutan Kenyataan. Jakarta: PT. Gramedia Pustaka Utama.

Leti, \& Sri. (2019). Pengaruh Disiplin Kerja, Loyalitas dan Pengembangan Karir Terhadap Kinerja Karyawan Yayasan Raudhatul Qur'an Batam. Benefita, 4(3), 560-596.

Mahfud, \& Ratmono. (2013). Analisis SEM-PLS Dengan WarpPLS 3.0. Yogyakarta: Andi. 
Mangkunegara, Anwar, Prabu. (2018). Manajemen Sumber Daya Manusia. Bandung: Remaja Rosdakarya Offset.

Mohamad Zainuri, \& Mahfayeri. (2017). Konsep Integritas. Riau: Pemerintah Provinsi Riau (Diseminasi Gugus Depan).

Noviyanti Rianti, \& Sri Langgeng. (2019, Juli). Pengaruh Tingkat Pendidikan, Pelatihan, Dan Pengembangan Karir Terhadap Kinerja Karyawan PT. Asuransi Takaful Batam. Jurnal Akuntansi, Ekonomi, dan Manajemen Bisnis, Vol. 7(No. 1), 48-55.

Ranti Melasari. (2017). Pengaruh Sistem Informasi Akuntansi Terhadap Kinerja Karyawan Dengan Integritas Karyawan Sebagai Variabel Pemoderasi Pada Perbankan Di Tembilahan. Jurnal Akuntansi Dan Keuangan, Vol. 6(No. 1).

Rivai, Veithzal. (2016). Manajemen Sumber Daya Manusia Untuk Perusahaan. Depok: PT. Raja Grafindo Persada.

Salwa, Away, \& Tabrani. (2018). Pengaruh Komitmen,
Integritas, dan Kompetensi Terhadap Kinerja Pegawai Serta Dampaknya Pada Kinerja Komisi Independen Pemilihan (KIP) Aceh. Jurnal Magister Manajemen Fakultas Ekonomi dan Bisnis Unsyiah, Vol 2(1), 58-67.

Siagian, P, Sondang (2016). Manajemen Sumber Daya Manusia. Jakarta: PT. Bumi Aksara.

Sri Rahayu, \& Silvia Anggraini. (2019). Pengaruh Disiplin Kerja, Motivasi, dan Pengembangan Karir Terhadap Kinerja Pegawai Graha Bumi Putera Di Surabaya. STEI MAHARDHIKA.

Sugiyono. (2019). Metode Penelitian Kuantitatif dan Kualitatif, dan R\&D (Edisi Kedua). Bandung: ALFABETA.

Wibowo. (2016). Manajemen Kinerja. Jakarta: PT. RajaGrafindo Persada. 